\title{
Peirce's Reception in Australia and New Zealand
}

\section{Catherine Legg}

\section{OpenEdition}

\section{Journals}

Electronic version

URL: http://journals.openedition.org/ejpap/507

DOI: 10.4000/ejpap.507

ISSN: 2036-4091

\section{Publisher}

Associazione Pragma

\section{Electronic reference}

Catherine Legg, " Peirce's Reception in Australia and New Zealand », European Journal of Pragmatism and American Philosophy [Online], VI-1 | 2014, Online since 08 July 2014, connection on 17 March 2020. URL : http://journals.openedition.org/ejpap/507 ; DOI : https://doi.org/10.4000/ejpap.507

This text was automatically generated on 17 March 2020.

Author retains copyright and grants the European Journal of Pragmatism and American Philosophy right of first publication with the work simultaneously licensed under a Creative Commons Attribution-

NonCommercial-NoDerivatives 4.0 International License. 


\title{
Peirce's Reception in Australia and New Zealand
}

\author{
Catherine Legg
}

1 An early Peirce enthusiast was Douglas Gasking, who taught from the mid-1940s to the mid-1970s at University of Melbourne. Gasking was particularly interested in applying Peircean ideas to epistemology, and his "Inductive and Deductive Arguments" (delivered at the NZ Division of the Australasian Association of Philosophy conference in 1972) discusses Peirce's famous bean-in-the-bag examples in detail. Gasking was also an early noter of Peirce's influence on the later Wittgenstein through Ramsey (in "Wittgenstein's Influence" which alas remains unpublished). The introduction to a posthumous Gasking anthology states, "In his last weeks Douglas was still reading his beloved 'Charlie Peirce"' (Gasking 1996, 13). Gasking's interest in Peirce was furthered at University of Melbourne through the 1970s and 1980s by his student Len O'Neill, who consciously entitled his long-running, widely-esteemed second-year epistemology course "Philosophy of Inquiry," and published a discussion of Peirce's claim that hypotheses that predict new (as opposed to known) data are more valuable (O’Neill 1993).

2 Meanwhile, the trail-blazing New Zealand philosopher Arthur Prior, who taught at University of Canterbury from the mid-1940s until in 1958 he departed for the UK, was one of the first English-speaking logicians to appreciate the true scope and depth of Peirce's logical contribution. The mere two published papers which Prior explicitly dedicated to discussing Peirce (Prior 1958; 1964) belie his wide reading in Peirce's papers, which contributed much to the development of his innovative tense logic. In particular, Prior saw his modal formalization of branching time as a way to work out Peirce's philosophical ideas on chance, necessity and human freedom.

3 Through the 1980s and 1990s Maurita Harney, who studied at University of Melbourne before completing a PhD in philosophy of language at Australian National University, took a pioneering interest in Peirce's semiotics. She used it to explore phenomenological and hermeneutic approaches to philosophy of mind, language, and computing, and put it to innovative use teaching philosophy of management at 
Swinburne University of Technology. Most recently she has been contributing to the emerging area of biosemiotics, drawing inspiration from Peirce and Merleau-Ponty.

The 1990s saw the emergence of some dedicated Peirce scholars in Australia: Anne Freadman, Professor of French at the Universities of Queensland and then Melbourne, measured Peirce's semiotics up against structuralist and post-structuralist thought in her rich book (Freadman 2004). Music scholar Naomi Cumming became fascinated by the application of Peirce's semeiotics to the expression of personality in performance, and published a fine book (Cumming 2000) before dying at the tragically young age of 38. Meanwhile Catherine Legg, studying realism with "hard-headed" Australian realists at Australian National University, became convinced that Peirce's scholastic realism could very usefully open up debates in this area, completing her PhD on Peirce's "Modes of Being" and since publishing a number of further papers on scholastic realism and iconicity (Legg 2008). In the early 2000s a further Peirce scholar was imported from the UK by Macquarie University: Albert Atkin, who obtained his PhD under Christopher Hookway and has subsequently published on Peircean philosophy of language (Atkin 2008).

Through the mid-1990s to the present day, Australia has seen a modest flourishing of what is now known as neo-pragmatism, mainly centered around University of Sydney and the Australian philosophers Huw Price (who became interested in pragmatism through anti-realist musings about time) and David Macarthur (who wrote a PhD on pragmatism at Harvard under Hilary Putnam). This has led to some discussion of Peirce as part of broader engagements concerning representationalism, expressivism, normativity and naturalism. Finally at University of Sydney one must also mention Paul Redding, whose wide-ranging and impressively thorough work in the history of modern philosophy, with particular focus on the 18th and 19th century figures of Kant and Hegel, has inevitably led him to consider Peirce, most notably in Redding (2003).

6 Although I think it is far to say that in what natives of this part of the world call "downunder," Peirce is still a minority interest, appreciation of his work appears to be growing slowly but surely.

\section{BIBLIOGRAPHY}

ATKIN A., (2008), “Peirce's Final Account of Signs and the Philosophy of Language," Transactions of the Charles S. Peirce Society 44 (1), 63-85.

CUMming N., (2000), The Sonic Self: Musical Subjectivity and Signification, Bloomington and Indianapolis, Indiana University Press.

FREADMAN A., (2004), The Machinery of Talk: Charles Peirce and the Sign Hypothesis, Stanford, Stanford University Press.

GASKING D., (1996), Language, Logic and Causation: Philosophical Writings of Douglas Gasking, I. T. Oakley - L. J. O’Neill (eds), Melbourne, Melbourne University Press. 
LEGG C., (2008), “The Problem of the Essential Icon,” American Philosophical Quarterly 45 (3), 207-32.

O'NEILL L., (1993), "Peirce and the Nature of Evidence," Transactions of the Charles S. Peirce Society 29 (2), 211-24.

PRIOR A. N., (1958), “Peirce's Axioms for Propositional Calculus,” The Journal of Symbolic Logic 23 (2), 135-36.

PRIOR A. N., (1964), “The Algebra of the copula," Studies in the Philosophy of Charles Sanders Peirce, Second Series, E. C. Moore - R. S. Robin (eds), Amherst, University of Massachusetts Press, 79-94.

REDDING P., (2003), "Hegel and Peircean Abduction," European Journal of Philosophy 11 (3), 295-313.

\section{AUTHOR}

\section{CATHERINE LEGG}

University of Waikato, New Zealand

clegg[at]waikato.ac.nz 